\title{
Changes in streamflow regimes and their response to different soil and water conservation measures in Loess Plateau watersheds
}

\author{
Shuyu Zhang ${ }^{1}$, Guangju Zhao ${ }^{2}$, Xingmin $\mathrm{Mu}^{2}$, and Peng Tian ${ }^{1}$ \\ ${ }^{1}$ Northwest A\&F University \\ ${ }^{2}$ Institute of Soil and Water Conservation Chinese Academy of Sciences and Ministry of \\ Water Resources
}

April 2, 2021

\begin{abstract}
Investigating the changes in streamflow regimes is useful for understanding the mechanisms associated with hydrological processes in different watersheds and for providing information to facilitate water resources management. In this study, we selected three watersheds, i.e., Sandu River, Hulu River, and Dali River on the Loess Plateau, to examine the changes in the streamflow regimes and to determine their responses to different soil and water conservation measures (terracing, afforestation, and damming). The daily runoff was collected continuously by three hydrological gauges close to the outlets of the three watersheds from 1965 to 2016. The eco-surplus, eco-deficit, and degree of hydrological change were assessed to detect hydrological alterations. The Budyko water balance equation was applied to estimate the potential impacts of climate change and human activities on the hydrological regime changes. Significant decreasing trends $(\mathrm{P}<0.05)$ were detected in the annual streamflow in the Sandu and Dali River watersheds, but not in the Hulu River watershed where afforestation dominated. The annual eco-surplus levels were low and they decreased slightly at three stations, whereas the eco-deficit exhibited dramatic increasing trends in the Sandu and Dali River watersheds. In the Sandu River watershed (dominated by terraces), the runoff exhibited the most significant reduction and the eco-deficit was the highest among the three watersheds. The integral degrees of hydrological change were higher in the Sandu River watershed than the other two watersheds, thereby suggesting substantial variations in the magnitude, duration, frequency, timing, and rate of change in the daily streamflow. In the Dali River watershed (dominated by damming), the changes in the extreme flow were characterized by a decreasing number appearing in high flow. In these watersheds, human activities accounted for $74.1 \%$ and $91.78 \%$ of the runoff reductions, respectively. In the Hulu River watershed (dominated by afforestation), the annual runoff exhibited an insignificant decreasing trend but with a significant increase in the low flow duration. Rainfall changes accounted for $64.30 \%$ of the runoff reduction.
\end{abstract}

\section{Hosted file}

ED Manuscript-zsy.pdf available at https://authorea.com/users/405372/articles/516377-changesin-streamflow-regimes-and-their-response-to-different-soil-and-water-conservationmeasures-in-loess-plateau-watersheds

\section{Hosted file}

Figure1-t.pdf available at https://authorea.com/users/405372/articles/516377-changes-instreamflow-regimes-and-their-response-to-different-soil-and-water-conservation-measuresin-loess-plateau-watersheds 


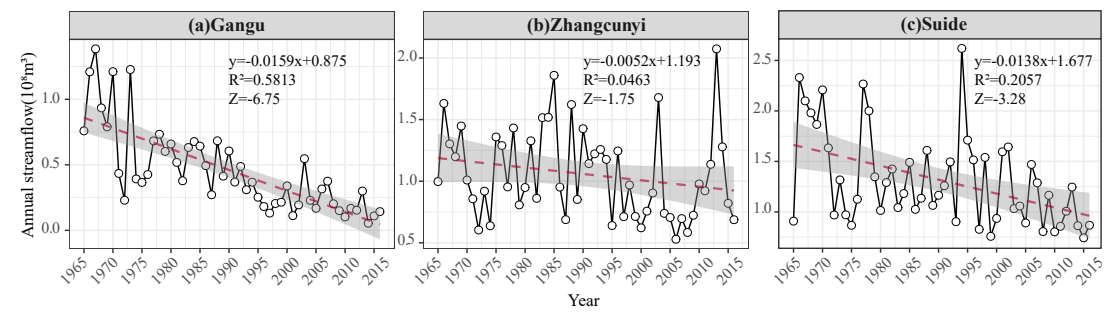

Figure 2 Trend analysis based on the annual streamflows in the three watersheds
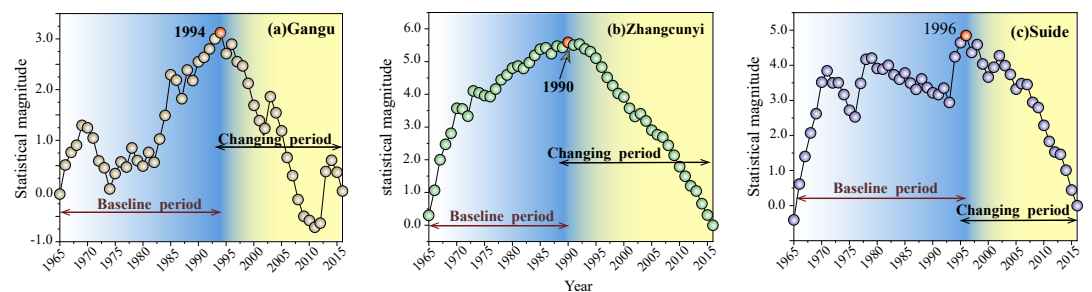

Figure 3 Abrupt changes in streamflows detected at the three stations 


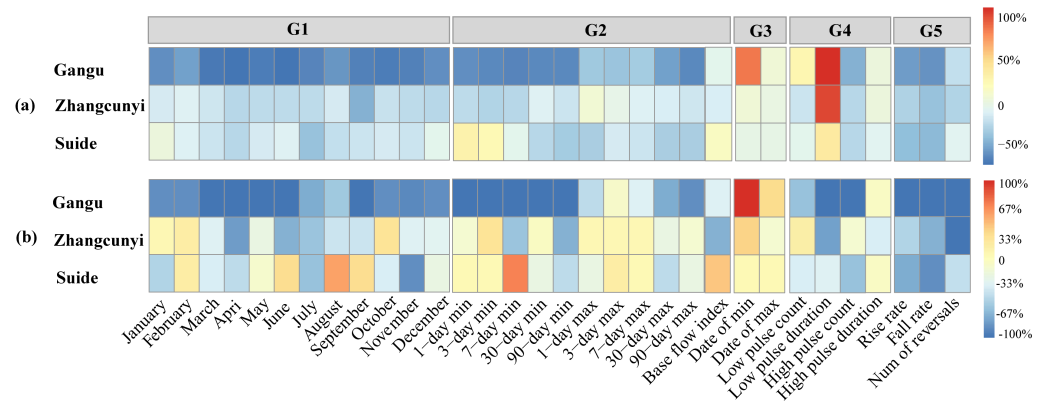

Figure 4 Change rates (a) and degree of hydrological change (b) for the 32 IHA indicators at six gauging stations

(G1: Magnitude of monthly water conditions; G2: magnitude and duration of annual extreme water conditions; G3: timing of annual extreme water conditions; G4: frequency and duration of high and low pulses; G5: rate and frequency of water condition changes)
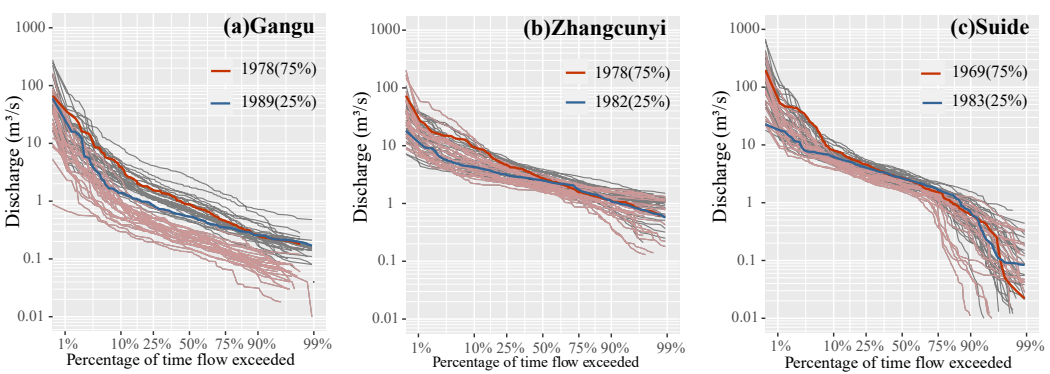

Figure 5 Flow duration curves (FDC) before (grey curves) and after change (pink curves) periods at the three stations 

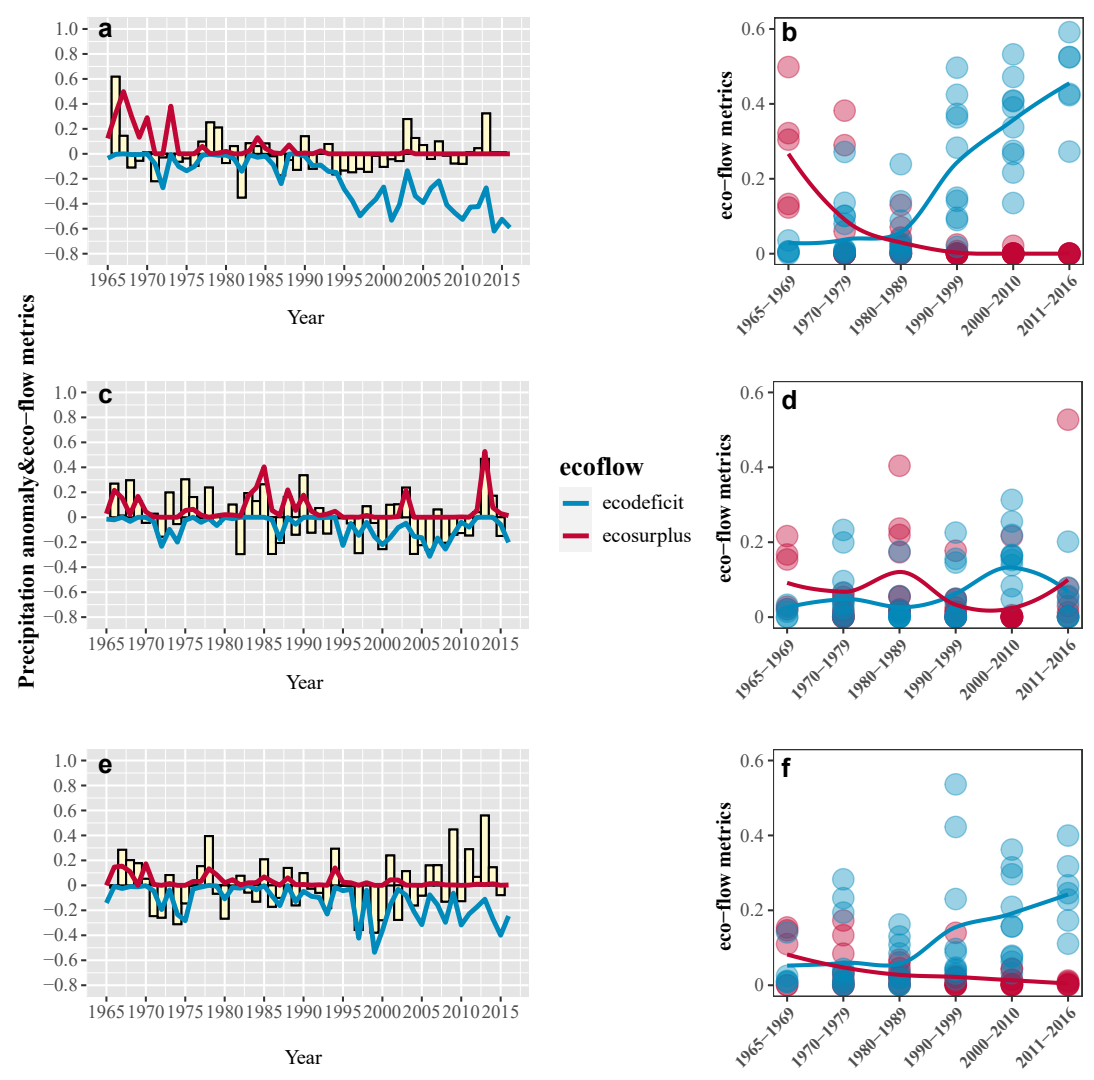

Figure 6 Annual variations in the eco-flow metrics and precipitation anomaly (a, c, and e) and decadal variations in the annual eco-flow metrics ( $b, d$, and $f)$ at three stations 

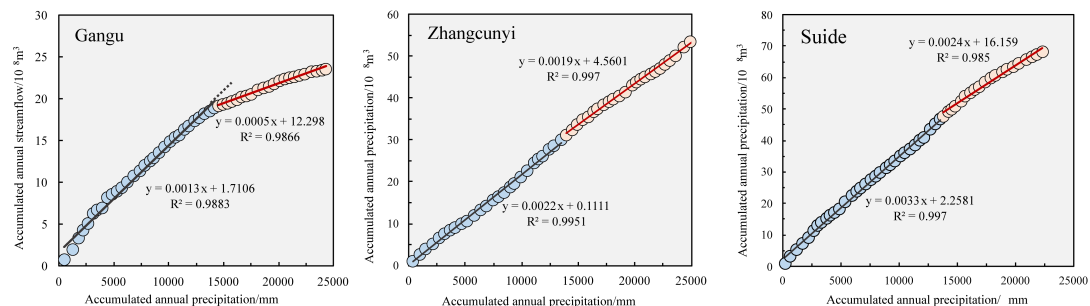

Figure 7 Double mass curve analysis of streamflow and precipitation at different stations

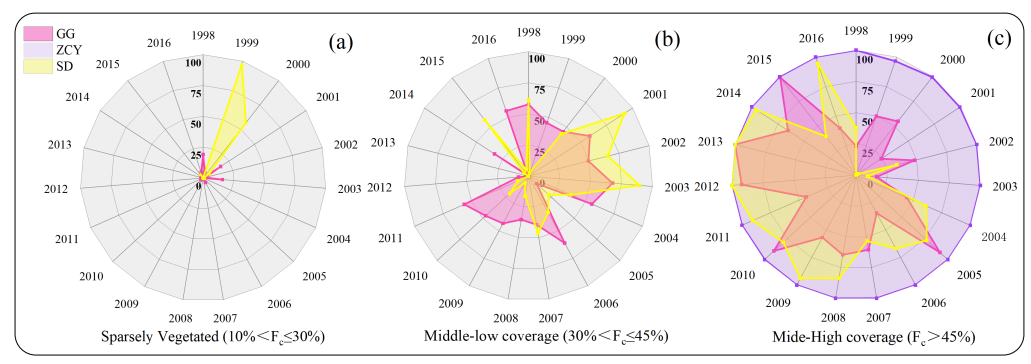

Figure 8 Changes in the vegetation coverage levels over time at the three stations

\section{Hosted file}

Figure9-t.pdf available at https://authorea.com/users/405372/articles/516377-changes-instreamflow-regimes-and-their-response-to-different-soil-and-water-conservation-measuresin-loess-plateau-watersheds

\section{Hosted file}

Table.pdf available at https://authorea.com/users/405372/articles/516377-changes-instreamflow-regimes-and-their-response-to-different-soil-and-water-conservation-measuresin-loess-plateau-watersheds 